\title{
Academic Anxiety among Reserved \& Non-Reserved Category Senior Secondary School Students of Jammu Division
}

\author{
Mohd Abid Siddiqui ${ }^{1} \&$ Atieq Ul Rehman ${ }^{1}$ \\ ${ }^{1}$ Department of Education, Aligarh Muslim University, India \\ Correspondence: Mohd Abid Siddiqui, Department of Education, Aligarh Muslim University, Uttar-Pradesh \\ 202002 India. Tel: 91-941-252-7204. E-mail: abidamu12@gmail.com; atiequlrehman489@gmail.com
}

Received: February 20, 2016

Accepted: February 25, 2016

Online Published: March 3, 2016

doi:10.20849/aes.v1i1.35

URL: http://dx.doi.org/10.20849/aes.v1i1.35

\begin{abstract}
Background: Indian society constitutes minorities, schedule castes, schedule tribes, and other backward communities. In order to uplift them through different policies and plans Government of India in consultation with Jammu and Kashmir Government had kept them in reserved (SC, ST, OBC, RBA, ALC) \& non-reserved (General/Open) category. Does students belonging to reserved \& non-reserved category differ in terms of their academic anxiety has motivated the researcher to approach this problem.

Aim: The main objectives of the study were to find out the relationship between academic anxiety, intelligence and study habits of total sample groups and sub-groups. To explore category (reserved \& non-reserved) and gender (male \& female) differences in academic anxiety, intelligence and study habits of total sample groups and sub-groups and to find out significance of difference in the mean scores of academic anxiety among all comparative groups under study.

Method: A sample of 537 students including 329 reserved categories and 208 non-reserved category students aged between 14-18 years were selected through stratified random sampling technique. Data was collected by administering self-constructed Academic Anxiety Scale bearing dependable validity and reliability, Standardised Group Test of Intelligence by Ahuja (2009) and Study Habits Inventory by Lajwanti, Chandel, \& Paliwal. (2013).

Results: Academic anxiety was correlated with intelligence and study habits of total sample groups and sub-groups under study. On an average students belonging to non-reserved category were higher in academic anxiety scores but were possessing better study habits than reserved categories students. In terms of academic anxiety's mean score differences among all comparative groups under study, only reserved categories females were suffering more from academic anxiety than reserved categories males sample.

Conclusion: More research on psychological health of reserved \& non-reserved categories students especially in their socio-cultural and political context is needed so as to evolve effective and practical preventive measures.
\end{abstract}

Keywords: academic anxiety, government of india, government of jammu \& kashmir, reserved backward area (RBA), actual line of control (ALC)

\section{Introduction}

Anxiety is one of the most common psychological disorders in school-aged children and adolescents worldwide (Costello, Mustillo, Erkanli, Keeler, \& Angold, 2003). The prevalence rates range from $4.0 \%$ to $25.0 \%$, with an average rate of $8.0 \%$ (Bernstein \& Borchardt, 1991; Boyd, Kostanski, Gullone, Ollendick, \& Shek, 2000). Anxiety is considered to be a universal phenomenon existing across cultures, although its contexts and manifestations are influenced by cultural beliefs and practices (Good \& Kleinman, 1985; Guarnaccia, 1997). In India, the main documented cause of anxiety among school children and adolescents is parents' high educational expectations and pressure for academic achievement (Deb \& Walsh, 2010a). Secondary school stage is an important stage of education as it opens the window for the students to select their streams (Science \& Non-Science) of study which further leads to professional courses like Engineering and Medicine. These are the most preferred choices as these courses lead to better job prospects. In India as well as abroad students seeking entry to these professional courses face tough competition and thus requires rigorous efforts to qualify the entrance test. It is because of this undue pressure in absence of any guidance programme students may come across various emotional problems. Such common problems encountered by adolescents are anxieties about 
different aspects of study, fear of examinations, general stress, depression, relationship difficulties, eating problems, loneliness and homesickness, lack of self-confidence or low self-esteem self-injury, suicidal thoughts, aggression, worries about success etc as reported by (Sodhi, Chabra, \& Goel, 2012; Pathak et al., 2011; Mohanraj \& Subbaiah, 2010). Kaur (2006) revealed that major areas of change and challenges that an individual passes through during adolescence age are physiological, cognitive, psychological and emotional changes. Study conducted by Reddy (1989) aimed to identify problem areas of adolescents in the school indicated that most of the problems were concentrated on academic anxiety followed by anxiety regarding their future. Verma \& Gupta (1990) explored that academic stress was caused due to examination system, burden of homework and attitudes of parents and teachers.

Academic anxiety is a common problem among all students and difficult to ignore if they want to succeed in academics. It becomes a problem that need immediate solution when the amount experienced grows so excessive that a student is no longer able to function productively. Feelings of anxiety are not inherently abnormal but can become severe enough to impair functioning in some individuals. When functioning is significantly impaired, one or more anxiety disorders may be diagnosed (APA, 2000). There are various factors that are responsible for causing severe academic anxiety among adolescents. These may be personal like poor intelligence, poor study habits, low self-esteem in terms of academic activities, poor health and adjustment etc. Familial factors may also induce severe anxiety like low socio-economic status, poor home environment, uneducated parents, family traditions so on and so forth. Institutional factors may be responsible for provoking severe academic anxiety among students like stiff competition, untrained teachers etc. Political factors may be war, law and order problems etc. Social-cultural factors may include discrimination based on caste, colour, region, religion, creed and gender.

India is multicultural and pluralistic society. There are various communities in Indian societies that are socially deprived since centuries. The framers of the Indian Constitution believed that weaker sections of the society were historically oppressed and thus under-represented in nation building activities. In order to bring these sections into mainstream the policy of reservation in 1947 was implemented in the country by providing $15 \%$ and $7.5 \%$ of vacancies to government aided educational institutes and for jobs in the government/public sector, as reserved quota for the SC and ST candidates with the objective of ensuing them to provide level playing field. OBCs are entitled to $27 \%$ reservations in public sector employment and higher education (Department of Personnel and Training, GOI, 2014). Further, Article 46 of Indian constitution clearly stated that the state shall promote with special care the educational and economic interests of the weaker sections of the people, and in particular, of the Scheduled Castes and the Scheduled Tribes, and shall protect them from social injustice and all forms of exploitation. Do the students from reserved \& non-reserved (General/Open) categories differ in terms of their academic anxiety, intelligence and study habits has motivated the researcher to carry out the present investigation.

\section{Objectives of the Study-For Carrying out the Present Investigation Following Objectives Were Framed}

To determine the strength of relationship between academic anxiety, intelligence and study habits among total sample groups

To find out the strength of relationship between academic anxiety, intelligence and study habits among total sample sub-groups

To compare academic anxiety, intelligence and study habits among reserved and non-reserved category, male and female students

To know the significance of difference in the mean scores of academic anxiety among all comparative groups under study

\section{Hypotheses of the Study}

$\mathbf{H}_{\mathbf{0}} \mathbf{1}$ : "There would be no significant relationship between academic anxiety, intelligence and study habits among total sample groups"

$\mathbf{H}_{\mathbf{0}}$ 2: "There would be no significant relationship between academic anxiety, intelligence and study habits among total sample sub-groups"

$\mathbf{H}_{0}$ 3: "There would be no significant difference in academic anxiety among reserved and non-reserved, male and female students"

$\mathbf{H}_{0}$ 3.1: "There would be no significant difference in intelligence among reserved and non-reserved, male and female students"

H03.2: "There would be no significant difference in study habits among reserved and non-reserved, male and female students" 
$\mathbf{H}_{\mathbf{0}}$ 4: "There would be no significant difference in the mean scores of academic anxiety among all comparative groups under study"

\section{Method \& Procedure}

\subsection{Sample}

A sample of 537 students comprising reserved and non-reserved category students was selected by using stratified random sampling technique from three districts (Jammu, Samba and Poonch) of Jammu and Kashmir.

\subsection{Tools Used}

Three standardized research tools were administered for collecting the data for present study.

1. Academic Anxiety Scale developed by the authors of this paper bearing significant validity and reliability.

2. Group Test of Intelligence developed by Ahuja. (2009).

2. Study Habits Inventory developed by Lajwanti, Chandel, \& Paliwal. (2013).

\section{Statistical Techniques Used}

Co-efficient of correlation, 2-way ANOVA and T-test were the statistical techniques for analyzing the data. Analysis was done by using SPSS Software.

\section{Analysis and Interpretation of Results}

$\mathbf{H}_{\mathbf{0}} \mathbf{1}$ : "There would be no significant relationship between academic anxiety, intelligence and study habits among total sample groups"

Table 1. Correlation between academic anxiety, intelligence and study habits among total sample groups

\begin{tabular}{llllll}
\hline $\begin{array}{l}\text { Predictive } \\
\text { Variables }\end{array}$ & \multicolumn{5}{c}{ Criterion Variable-Academic Anxiety } \\
\hline & $\begin{array}{l}\text { Total Sample } \\
(\mathrm{N}=537)\end{array}$ & $\begin{array}{l}\text { Total Reserved } \\
\text { Categories } \\
(\mathrm{N}=329)\end{array}$ & $\begin{array}{l}\text { Total } \\
\text { Non-Reserved } \\
\text { Category }(\mathrm{N}=208)\end{array}$ & $\begin{array}{l}\text { Total Male } \\
(\mathrm{N}=290)\end{array}$ & $\begin{array}{l}\text { Total } \\
\text { Female } \\
(\mathrm{N}=247)\end{array}$ \\
\hline Intelligence & $-0.26^{* *}$ & $-0.47^{* *}$ & -0.01 & $-0.26^{* *}$ & $-0.25^{* *}$ \\
Study Habits & $0.12^{* *}$ & $0.18^{* *}$ & -0.03 & $0.30^{* *}$ & -0.01 \\
\hline
\end{tabular}

**Significant at 0.01 level

The coefficient of correlation presented in Table- 1 between academic anxiety and intelligence is $(r=-0.26)$ for total sample, $(\mathrm{r}=-0.47)$ for reserved categories students, $(\mathrm{r}=-0.1)$ for non-reserved categories students, $(\mathrm{r}=$ $-0.26)$ for male students and $(\mathrm{r}=-0.25)$ for female students' sample. All correlational values were negative and significant at 0.01 level of confidence except total non-reserved category sample. It can be inferred that students who performed better on intelligence test performed poorly on academic anxiety scale indicating that intelligent students exhibited low academic anxiety. Similar, findings were reported by Singh (2010a) that relationship between anxiety and intelligence was significantly negative. Similarly, the coefficient of correlations for different sample groups between study habits and academic anxiety was calculated and found to be positive $(\mathrm{r}=0.12)$ for total sample, $(\mathrm{r}=0.18)$ for reserved categories students, $(\mathrm{r}=-0.3)$ for non-reserved category students, but insignificant, $(\mathrm{r}=0.30)$ for male students. Insignificant and negative relationship ( $\mathrm{r}=-0.1)$ was found between academic anxiety and study habits for female students sample. It can be interpreted that increase in study habits score leads to corresponding increase in academic anxiety scores among all groups except total non-reserved category students and total female students sample. Similar findings were reported by (Kumar, 2013; Raju \& Afsaw, 2009) that decrease in study habits would lead to increase in test anxiety. Hence, hypothesis no. 1 is partially rejected

$\mathbf{H}_{\mathbf{0}}$ 2: "There would be no significant relationship between academic anxiety, intelligence and study habits among total sample sub-groups" 
Table 2. Correlation between academic anxiety, intelligence and study habits among total sample sub-groups

\begin{tabular}{lllll}
\hline Predictive Variables & \multicolumn{4}{l}{ Criterion Variable-Academic Anxiety } \\
\hline & Reserved & Reserved & Non-Reserved & Non-Reserved \\
& $\begin{array}{l}\text { Categories Male } \\
(\mathrm{N}=172)\end{array}$ & $\begin{array}{l}\text { Categories } \\
\text { Female }\end{array}$ & $\begin{array}{l}\text { Male } \\
(\mathrm{N}=157)\end{array}$ & $\begin{array}{l}\text { Female } \\
(\mathrm{N}=118)\end{array}$ \\
& & $-0.44^{* *}$ & 0.05 & -0.09 \\
\hline Intelligence & $-0.48^{* *}$ & -0.00 & -0.09 & 0.01 \\
Study Habits & $0.44^{* *}$ & & & \\
\hline
\end{tabular}

**Significant at 0.01 level

Table-2 shows the correlation values between criterion variable (academic anxiety) and predictor variables for four sub-groups of the sample. It depicts significant negative relationship between intelligence and academic anxiety which is calculated to be $\left(r_{-}=0.48\right)$ for reserved categories male, $\left(r_{=}-0.44\right)$ for reserved categories female, $\left(\mathrm{r}_{=} 0.5\right)$ for non-reserved category male students but insignificant and $\left(\mathrm{r}_{=}-0.09\right)$ for non-reserved category female sample. The coefficient of correlation between study habits and academic anxiety was calculated and the obtained values are $\left(\mathrm{r}_{-} 0.44\right)$ for reserved categories male sample, $\left(\mathrm{r}_{-}=0.00\right)$ for reserved categories female sample, $\left(r_{-}-0.09\right)$ for non-reserved category male and $\left(r_{=} 0.1\right)$ for non-reserved category female samples. All correlational values between sub-groups mentioned above are insignificant except total reserved categories male sample. Similar findings were reported by Lawrence (2014) that there was no significant relationship between study habits and test anxiety. So, hypothesis no. 2 is partially accepted.

$\mathbf{H}_{0} 3$ : "There would be no significant difference in academic anxiety among reserved and non-reserved, male and female students"

Table 3. Difference in academic anxiety between reserved and non-reserved categories and gender

\begin{tabular}{llllllll}
\hline $\begin{array}{l}\text { Source of } \\
\text { Variance }\end{array}$ & Categories & $\mathrm{N}$ & Mean & $\begin{array}{l}\text { Sum of } \\
\text { Squares }\end{array}$ & 'df' & $\begin{array}{l}\text { Mean } \\
\text { Square }\end{array}$ & F-ratio \\
\hline \multirow{2}{*}{ Categories } & Reserved & 329 & 56.96 & 226.14 & 1 & 226.14 & $1.84^{*}$ \\
& Non-Reserved & 208 & 58.22 & & & & \\
& Male & 290 & 56.63 & 450.36 & 1 & 450.36 & 3.66 \\
Gender & Female & 247 & 58.41 & & & & \\
Categories $\times$ Gender & & & 666.19 & 1 & 666.19 & $5.42^{* *}$ \\
Error & & & & 65458.95 & 533 & 122.81 & - \\
Total & & & 1839415.00 & 537 & - & - \\
\hline
\end{tabular}

**Significant at 0.01 level, *Significant at 0.05 level

It is evident from the Table- 3 that there exists a significant difference between students of reserved and non-reserved categories in regard to their academic anxiety. The calculated F-value (1.84) is significant at 0.05 level of confidence. It is further clear that the mean value of reserved category students (56.96) is lesser than the non-reserved categories students (58.22) indicating higher academic anxiety among non-reserved category students. The said table also reveals that calculated F-value (3.66) for male and female groups is insignificant. It means that no significant difference is found between reserved \& non-reserved category, male \& female groups in regard to academic anxiety. Other research findings too revealed that gender does not have any impact on anxiety scores of school students (Shukla, 2013; Mahato \& Jangir, 2012; Mattoo \& Nabi, 2012; Lenka \& Kant, 2012; Dhull, 2012; Bhansali \& Trivedi, 2008; Verma, 1990; Saxena, 1988). Contradictory findings were reported by (Barinder, 1985; Mehrotra, 1986; Singh 2010b) that girls were prone to higher academic anxiety than boys. However, (Joshi, 2005; Deb \& Walsh, 
$2010 \mathrm{~b}$ ) reported that boys were more anxious than girls. Furthermore, the above Table also depicts that the interactional effect of streams and gender bearing F-ratio (5.42) is significant at 0.01 level of confidence.

It is really interesting to note that academic anxiety was more prevalent among non-reserved category students as compared to reserved categories students. This may be because students from non-reserved categories have to face open competition for securing admission in courses like engineering and medical sciences, which ultimately may lead them to higher academic anxiety. Hence, hypothesis no. 3 is partially rejected.

$\mathbf{H}_{0}$ 3.1: "There would be no significant difference in intelligence among reserved and non-reserved, male and female students"

Table 4. Difference in intelligence between reserved and non-reserved categories and gender

\begin{tabular}{llllllll}
\hline $\begin{array}{l}\text { Source of } \\
\text { Variance }\end{array}$ & Categories & $\mathrm{N}$ & Mean & $\begin{array}{l}\text { Sum of } \\
\text { Squares }\end{array}$ & 'df' & $\begin{array}{l}\text { Mean } \\
\text { Square }\end{array}$ & F-ratio \\
\hline Categories & Reserved & 329 & 79.27 & 19181.058 & 1 & 19181.058 & 1.35 \\
& Non-Reserved & 208 & 67.04 & & & & \\
\multirow{2}{*}{ Gender } & Male & 290 & 74.84 & 188.375 & 1 & 188.375 & $138.30^{* *}$ \\
& Female & 247 & 74.17 & & & & \\
Categories $\times$ Gender & & & 1004.747 & 1 & 1004.747 & $7.24^{* *}$ \\
Error & & & 73918.413 & 533 & 138.684 & - \\
Total & & & 3077405.000 & 537 & - & - \\
\hline
\end{tabular}

**Significant at 0.01 level

A glance over Table- 4 shows that there exists no significant difference between reserved and non-reserved category senior secondary school students on the measure of intelligence. The calculated F-value (1.35) is insignificant. The table also reveals that the $F$ value (138.30) for male and female groups is significant at 0.01 level of confidence. The mean value for male student (74.84) is higher than that of female student (74.17). It indicates that male students are found more intelligent as compared to female students. Contradictory findings were reported by Talwar, (2006) that intelligence level of female students was higher than male students. Furthermore, the Table shows that the interactional effect of categories and gender having F-value (7.24) is significant at 0.01 level of confidence. Thus, hypothesis no. 3.1 is partially rejected.

$\mathbf{H}_{0}$ 3.2: "There would be no significant difference in study habits among reserved and non-reserved, male and female students"

Table 5. Difference in study habits between reserved and non-reserved categories and gender

\begin{tabular}{llllllll}
\hline $\begin{array}{l}\text { Source of } \\
\text { Variance }\end{array}$ & Categories & $\mathrm{N}$ & Mean & $\begin{array}{l}\text { Sum of } \\
\text { Squares }\end{array}$ & 'df' & $\begin{array}{l}\text { Mean } \\
\text { Square }\end{array}$ & F-ratio \\
\hline Categories & Reserved & 329 & 129.88 & 9013.015 & 1 & 9013.015 & $93.91^{* *}$ \\
& Non-Reserved & 208 & 138.33 & & & & \\
Gender & Male & 290 & 133.62 & 57.799 & 1 & 57.799 & 0.60 \\
Female & 247 & 132.60 & & & & \\
Categories $\times$ Gender & & & 15.078 & 1 & 15.078 & 0.15 \\
Error & & & 51150.845 & 533 & 95.968 & - \\
Total & & & 9581667.000 & 537 & - & - \\
\hline
\end{tabular}

**Significant at 0.01 level 
An examination of the Table- 5 indicates a significant difference between reserved and non-reserved category students on the measure of study habits. The calculated F-value (93.91) is found to be significant at 0.01 level of confidence. In other words non-reserved category background students possess good study habits than their reserved categories counterparts as calculated mean value for non-reserved category students (138.33) is found to be much higher than (129.88) for reserved categories students. The above table also reveals that F-value (0.60) for male and female groups is not significant indicating that significant difference does not found between male and female students in regard to study habits. The interactional effect of categories and gender having F-value $(0.15)$ is also insignificant.

It can be inferred from the findings presented above that those students who are from non-reserved category are found possessing better study habits than reserved categories students belonging to SC, ST, OBC, RBA \& ALC. Those students who are from non-reserved category, their parents are well educated, economically well off, living in urban areas, can hire a tutor and they can afford private schools if government schools are not up to mark so on and so forth. This may be the reason for them to possess good study habits than their respective counterparts. Thus, hypothesis no. 3.2 is partially accepted.

$\mathbf{H}_{\mathbf{0}} 4$ : "There would be no significant difference in the mean scores of academic anxiety among all comparative groups under study"

Table 6. Significance of difference in the mean scores of academic anxiety among all comparative groups under study

\begin{tabular}{lllll}
\hline Comparable Groups & $\mathrm{N}$ & $\mathrm{M}$ & $\mathrm{SD}$ & t-value \\
\hline Reserved Categories males & 172 & 55.25 & 9.94 & -2.79 \\
Non-Reserved Category males & 118 & 58.65 & 10.57 & \\
Reserved Categories females & 157 & 58.85 & 12.00 & 0.75 \\
Non-Reserved Category females & 90 & 57.65 & 12.07 & \\
Reserved Categories males & 172 & 55.25 & 9.94 & $2.97^{* *}$ \\
Reserved Categories females & 157 & 58.85 & 12.00 & \\
Non-Reserved Category males & 118 & 58.65 & 10.57 & 0.63 \\
Non-Reserved Category females & 90 & 57.65 & 12.07 & \\
\hline Sificant at 0.01 level & & & &
\end{tabular}

**Significant at 0.01 level

From the Table- 6 presented above, it can be concluded that there is an insignificant difference between reserved categories males and non-reserved category male sample in regard to their academic anxiety as the obtained 't-value' (-2.79) is insignificant. It means the males of both categories have all most the same level of academic anxiety in case of present sample. The second comparative group reserved categories female and non-reserved category female students sample has also produced insignificant difference as the obtained ' $t$ ' value $(0.75)$ is statistically insignificant. However, in case of reserved categories male students' significant difference exists between mean values (55.25) of reserved categories male and reserved categories female samples (58.85). It shows that reserved categories female students were found suffering from higher academic anxiety as compared to reserved categories male sample. Finally, 't' value (0.63) between non-reserved male and non-reserved category female samples is also insignificant. Thus null hypothesis no. 4 is partially accepted.

\section{Conclusion and Suggestions}

On the basis of the findings discussed above we may conclude that academic anxiety is a general problem of senior secondary school students. However, it was higher among non-reserved categories total sample and reserved category female sample as compared to reserved category male students sample. The study has further revealed that intelligence and study habits are an important variable which affects the academic anxiety in a negative manner sometimes. Present study has also indicated that male students scored higher on intelligence test and non-reserved category students were possessing better study habits than their respective counterparts. Other differences in terms of academic anxiety, intelligence and study habits among all comparative groups under present study remained same. Present study was carried out on senior secondary school students belonging to reserved and non-reserved categories. Researches can be conducted on students belonging to reserved and 
non-reserved categories studying in higher education in terms of exploring their academic anxiety in relation to personal, familial, institutional, social and political factors. Following are the educational implications of present study.

Non-reserved categories students studying at senior secondary schools were more prone to severe academic anxiety. Concerted efforts are needed to create an environment in schools and at home free from anxiety by providing counseling to students for choosing appropriate stream (science/non-science) according to their abilities, interest, attitude, aptitude \& potential.

Teachers must create an environment in classroom free from anxiety by providing more attention to girls from reserved categories (SC, ST, OBC, RBA, ALC) and lower socio economic status because they suffer more from academic anxiety.

Male students had scored higher on intelligence test. It may be because of family obligations on female students, gender biasness of parents to provide extra care to male members of the society than female etc. They must be given appropriate attention inside the school so that they can achieve up to their potential in academics.

Non-Reserved Category (General/Open) category students were possessing better study habits. Class teachers should teach students from reserved categories (SC, ST, OBC, RBA, ALC) that how to develop good study habits, how to recall information, how to understand concepts, how to develop good comprehension in a particular subject so on and so forth.

Parents and Teachers must play an active role in minimizing the academic anxiety of students by expecting academic performance from students that is not beyond their abilities, interest, potentials etc. Over expectations from parents and teachers also lead students towards more academic anxiety.

Orientation programmes for the parents and teaches to make them aware about the importance of study habits in reducing the academic anxiety and enhancing the academic achievement should be organized on a regular basis. Such programmes will produce fruitful results if both parents of the students are encouraged to attend such programmes.

Guidance and counseling cell as advocated by Kothari Education Commission (1964-66) is the need of the hour at senior secondary schools. It is at this stage of education, students select their streams (science \& non-science) for further education. Guidance and counseling helps the students in selecting their courses in the light of their abilities, attitude, aptitude and interests. It is obvious that selection of wrong choices leads to lessening of interest towards study which further reduces the academic achievement. Ultimately, the student remains underachiever throughout his/her life.

\section{References}

Article-46. (1949). Promotion of educational and economic interests of Scheduled Castes, Scheduled Tribes and other weaker sections. Retrieved from https://en.wikisource.org/wiki/Constitution_of_India/Part_IV\#Article_46_.7BPromotion_of_educational_an d_economic_interests_of_Scheduled_Castes.2C_Scheduled_Tribes_and_other_weaker_sections.7D

Association, A. P. (2000). Definition of anxiety. Encyclopedia of Psychology. Retrieved from http://www.apa.org/topics/anxiety/index.aspx

Barinder, M. (1985). A study of general anxiety and test anxiety with reference to the environmental factors and extraversion-introversion of Delhi students. Ph.D. (thesis) Delhi University in Buch, M.B. (1988-92). Fifth Survey of Educational Research, New Delhi: NCERT.

Bernstein, G. A., \& Borchardt, C. M. (1991). Anxiety disorders of childhood and adolescence: A critical review. Journal of the American Academy of Child and Adolescent Psychiatry, 30, 519-532. http://dx.doi.org/10.1097/00004583-199107000-00001

Bhansali, R., \& Trivedi, K. (2008). Is academic anxiety gender specific: A comparative study. Journal of Social Science, $17(1), 1-3$.

Boyd, C. P., Kostanski, M., Gullone, E., Ollendick, T. H., \& Shek, D. T. L. (2000). Prevalence of anxiety and depression in Australian adolescents: Comparisons with worldwide data. The Journal of Genetic Psychology, 161, 479-492. http://dx.doi.org/10.1080/00221320009596726

Costello, E. J., Egger, H. L., \& Angold, A. (2003). Developmental epidemiology of anxiety disorders. In T. H. Ollendick, \& J. S. March (Eds.), Phobic anxiety disorders in children and adolescents: A clinician's guide 
to effective psychosocial and pharmacological interventions (pp. 61-91). Oxford, UK: Oxford University Press.

Deb, S., \& Walsh, K. (2010). Anxiety among high school students in India: comparisons across gender, school type, social strata and perceptions of quality time with parents. Australian Journal of Educational \& Developmental Psychology, 10, 18-31. Retrieved from https://www.newcastle.edu. au/_data/assets/pdf_file/0012/100290/V10_deb_et_al.pdf

Dhull, J. (2012). A comparative study of the achievement in science in relation to intelligence, academic anxiety and reading interest of the $10^{\text {th }}$ class students in government and private schools of Haryana. Unpublished, Maharshi Dayanand University, Haryana.

Good, B. J., \& Kleinman, A. M. (1985). Culture and anxiety: Cross-cultural evidence for the pattering of anxiety disorder. In H. A. Tuma, \& J. D. Maser (Eds.), Anxiety and anxiety disorders (pp. 297-323). Hillsdale, NJ: Lawrence Erlbaum Associates.

Government of India. (2014). Brochure on Reservation for SC, ST \& Other Backward Classes In Services. department of personnel and training. Retrieved from http://persmin.nic.in/DOPT/Brochure_Reservation_SCSTBackward/Ch-01_2014.pdf

Guarnaccia, P. J. (1997). A cross-cultural perspective on anxiety disorders. In S. Friedman (Ed.), Cultural issues in the treatment of anxiety (pp. 3-20). New York: Guilford.

Joshi. S. C. (2005). A comparative study of anxieties of the adolescent students of higher and lower economic strata. Journal of Community Guidance and Research, 22(3), 299-306.

Kumar, M. D. (2013). A study of academic achievement of school student in relation to their study habits, academic anxiety and academic motivation. New-Delhi, New Age International Private Limited.

Lawrence, A. S. A. (2014). Relationship between study habits and test anxiety of higher secondary students. International Journal of Teacher Educational Research, 3(6), 1-9. Retrieved from http://files.eric.ed.gov/fulltext/ ED545668.pdf

Lenka, S. K., \& Kant, R. (2012). A study of academic anxiety of special need's children in special reference to hearing impaired and learning disabled. Zenith International Journal of Multidisciplinary Research, 2(2), $12-18$.

Mahato, B., \& Jangir, S. (2012). A study on academic anxiety among adolescents of Minicoy Island. International Journal of Science and Research, 1(3), 12-14.

Mattoo, N. H., \& Nabi, R. (2012). A study on academic anxiety among adolescents (14-16 years). International Journal of Social Science Tomorrow, 1(3), 37-42.

Mehrotra, S. (1986). A study of the relationship between intelligence, socio economic status, anxiety, personality, adjustment and academic achievement of high school students. Ph.D. (thesis) Kanpur University. Buch, M. B. (1988-92). Fifth Survey of Educational Research, New Delhi: NCERT. 2, 836

Mohanraj, R., \& Subbaiah, K. (2010). Prevalence of depressive symptoms among urban adolescents in South India. Journal of Indian Association of Child Adolescents Mental Health, 33-43.

Pathak, R. S., Ravi. C., Parvan, U. C. Gupta, B. P., Ojha, R. K., \& Goel., N. K. (2011). Behavioural and emotional problems in school going adolescents. Australasian Medical Journal, 4(1), 15-21. http://dx.doi.org/10.4066/AMJ.2011.464

Raju, P. M., \& Asfaw, A. (2009). Recalled test anxiety in relation to achievement, in the context of general academic self-concept, study habits, parental involvement and socio-economic status among grade 6 Ethiopian students. International Journal of Primary, Elementary and Early Years Education, 37(3), 269-285. http://dx.doi.org/10.1080/03004270902734085

Saxena, V. (1988). A study of the impact of family relationship on adjustment, anxiety, achievement motivation, self-concept and academic achievement of high school students. Buch, M. B. (1988-92). Fifth Survey of Educational Research, New Delhi: NCERT.

Shukla. (2013). A study of the examination anxiety among the secondary school students in the context of some variables. India: Gujarat University.

Singh, S. (2010). Relationship of anxiety and emotional and social maturity with actualization of general mental ability of high school students. Unpublished, Guru Nanak Dev University: Amritsar. 
Sodhi, M. K., Chabra, G. S., \& Goel, S. (2012). Psycho-socio-demographic correlates of school problems in adolescent males in Amritsar district of Punjab. Journal of Healthline, 3(1), 10-15. Retrieved from http://www.iapsmgc.org/index_pdf/3.pdf

Talwar, V. (2006). Impact of anxiety, frustration, level of aspiration and intelligence on academic achievement. Unpublished, Attari College of Education, Bundelkhand University: Jhansi.

Verma, B. P. (1990). Sex related differences in risk taking, self-confidence and anxiety among adolescents learner. Indian Education Review, 25(4), 93-97.

\section{Copyrights}

Copyright for this article is retained by the author(s), with first publication rights granted to the journal.

This is an open-access article distributed under the terms and conditions of the Creative Commons Attribution license (http://creativecommons.org/licenses/by/3.0/). 